\title{
In-Situ High Temperature X-Ray Studies on Bainitic Transformation of Austempered Silicon Alloyed Steels
}

\author{
Esa Vuorinen ${ }^{1,}$,, Xiang Chen ${ }^{1,2, b}$ \\ ${ }^{1}$ Division of Engineering Materials, Department of Applied Physics and Mechanical Engineering, \\ Luleå University of Technology, SE-97187 Luleå, Sweden \\ ${ }^{2}$ Key Laboratory for Advanced Materials Processing Technology Ministry of Education of China, \\ Department of Mechanical Engineering, Tsinghua University, 100084 Beijing, China \\ aesa.vuorinen@ltu.se, bxchen@tsinghua.edu.cn
}

Keywords: silicon alloyed steel, bainitic ferrite, austempering, in-situ X-ray diffraction

\begin{abstract}
The in-situ X-ray diffraction observations of the bainitic transformation of silicon alloyed steels were performed using the high temperature X-ray diffraction technique. The experimental results have shown that the volume fraction and carbon content of austenite remains a constant value which indicate that the transformation is almost finished after the early stages of austempering transformation. Asymmetry diffraction peaks are obtained for samples at the early stage of transformation due to a heterogeneous distribution of carbon in different regions of austenite and thus exists two types of austenite: low-carbon austenite $\left(\gamma_{\mathrm{LC}}\right)$ and the high-carbon austenite $\left(\gamma_{\mathrm{HC}}\right)$. The experimental results supports that the bainite growth is by a non-diffusive mechanism when austempering temperature is in the lower bainite transformation temperature.
\end{abstract}

\section{Introduction}

Silicon alloyed steel [1-12] that has a fine duplex microstructure of bainitic ferrite and retained austenite (ausferrite) is a material of high interest, which demonstrates a combination of better mechanical properties such as strength, ductility, fatigue strength, fracture toughness, impact strength and wear resistance. No carbides will be precipitated in the structure because the silicon does not dissolve in the cementite and hence delays the austempering transformation of austenite. Silicon alloyed steel has great potential to be a low cost and high reliability structural material $[4,9]$.

The behavior of carbon during the austempering transformation of austenite to bainitic ferrite is a hot spot from the fundamental point of view. Usually X-ray diffraction analysis has been used to evaluate the volume fraction and the carbon concentration of retained austenite. However the conventional X-ray diffraction analysis can not give the true values of the volume fraction and carbon content of austenite while austempering transformation, because it is possible that some austenite containing less carbon transforms to martensite and some carbon diffuses into austenite during cooling to room temperature. So in order to clarify these uncertainties the in-situ X-ray diffraction technology is used in the research of bainitic transformation. Babu [13] used an intense synchrotron X-ray diffraction for time-resolved in-situ observation of the isothermal transformation of high-carbon austenite to bainitic ferrite. Stone [14] used high resolution synchrotron X-ray diffraction to conduct in-situ evaluation of phases during the isothermal growth of bainite.

The aim of this study is to investigate the phase transformation from austenite to bainitic ferrite of silicon alloyed steels using high-temperature X-ray equipment other than synchrotron radiation, to study the volume fractions and carbon contents in austenite and to study the lattice parameter changes of austenite at different austempering temperatures during the course of transformation. 


\section{Experimental procedures}

The chemical composition of the tested steels is presented in Table 1.

Table 1 Chemical composition of the tested steels [wt. \%]

\begin{tabular}{cccccccccc}
\hline Steel & $\mathrm{C}$ & $\mathrm{Si}$ & $\mathrm{Mn}$ & $\mathrm{Mo}$ & $\mathrm{P}$ & $\mathrm{S}$ & $\mathrm{Cr}$ & $\mathrm{Ni}$ & $\mathrm{V}$ \\
\hline $\mathrm{A}$ & 0.32 & 1.54 & $<0.01$ & 0.29 & $<0.001$ & 0.003 & 1.45 & 3.29 & 0.1 \\
\hline $\mathrm{B}$ & 0.83 & 2.15 & 0.47 & 0.36 & 0.027 & 0.027 & 0.051 & - & - \\
\hline
\end{tabular}

The forged steel A has been investigated earlier by F. G. Caballero [15]. The test samples were prepared following the experimental procedures of reference 15 . The test samples of cast steel B was produced in a $500 \mathrm{~kg}$ medium-frequency coreless induction furnace with siliceous lining, with charge materials of silicon steel scrap, graphite, Fe-Si, Fe-Mn and Fe-Mo master alloys. The melt was superheated to $1600^{\circ} \mathrm{C}$. After holding at the temperature for 5 minutes, the melt was cast into $\mathrm{Y}$ blocks by investment casting. All sample were cut from the bottom of the Y blocks.

A Philips X'pert-MPD X-ray diffractometer with a high-temperature diffractometer chamber HDK 2.4 was used to determine the volume fraction of austenite and carbon content in austenite. After grinding, the samples were final polished using $0.25 \mu \mathrm{m}$ diamond paste. The samples were positioned on a Mo sample holder in the furnace chamber, and were austenitized by resistance Mo-heating element at $900^{\circ} \mathrm{C}$ for 3 minutes. The samples were then cooled down to the austempering temperatures of $280^{\circ} \mathrm{C}$ for 176 minutes by using nitrogen. The in-situ XRD observations were done using a monochromatic $\mathrm{Cu}-\mathrm{K} \alpha$ radiation at $40 \mathrm{kV}$ and $45 \mathrm{~mA}$. A PW3011/00 proportional rotating head anode diffractometer was used to scan the angular $2 \theta$ range of $41.5-45.5^{\circ}$, scanning time of every peak was $3 \mathrm{~min} 28 \mathrm{sec}$ ( $\operatorname{step} 0.1^{\circ}$, time per step is 5 second). The systematic errors in the measurements of the positions of austenite and bainitic ferrite peaks were corrected by a pure single-crystal silicon plate. The profiles were analyzed on a computer to obtain the exact peak positions and the integrated intensity of the $\{111\}$ planes of austenite and the $\{110\}$ planes of bainitic ferrite by using the curve-fitting technique with a Gaussian function. The volume fraction of austenite $(\mathrm{X} \gamma)$ was determined by the direct comparison method [16] using the integrated intensities of the $\{110\}$ planes of ferrite and the $\{111\}$ planes of austenite. The following equation [17] was used to determine the carbon content of austenite at room temperature:

$$
\begin{aligned}
a_{\gamma}= & 0.3578+0.0033 x_{C}+0.000095 x_{M n}-0.00002 x_{N i}+0.00006 x_{C r}+0.0022 x_{N} \\
& +0.00056 x_{A l}+0.00015 x_{C u}+0.00031 x_{M o}+0.00039 x_{T i}+0.00018 x_{V}
\end{aligned}
$$

where $\alpha_{\gamma}$ is the lattice parameter of austenite in $\mathrm{nm}$ and $x_{C}$ is the carbon content of austenite in wt. $\%$. The label $x_{i}$, corresponds to the weight percent of elements " $i$ " in the austenite. The lattice parameters of retained austenite and bainitic ferrite were estimated using the $\{111\}$ planes of austenite and $\{110\}$ planes of ferrite respectively.

The microstructures of the samples were then examined on a Jeol JSM 6460 scanning electron microscope (SEM) using an accelerating voltage of $15 \mathrm{kV}$ after etching with $3 \%$ nital solution.

\section{Results and discussion}

Volume fractions and carbon contents of austenite during in-situ evolution of bainitic ferrite transformation

The volume fraction of austenite of in-situ X-ray analyses of the bainitic transformation of the two 
steels during the isothermal transformation at $280^{\circ} \mathrm{C}$ is shown in Figure 1. Bainitic ferrite transformation of steel B develops much more rapid than steel A at the early stages of austempering transformation which confirms that high concentration of alloying elements can retard the bainitic transformation rate. The rate of transformation decreases with the austempering time and the transformation is almost finished after about 1700 seconds and 870 seconds for steel A and B respectively when the volume fraction of austenite does not change anymore, which shows that the reaction remains thermodynamically incomplete.

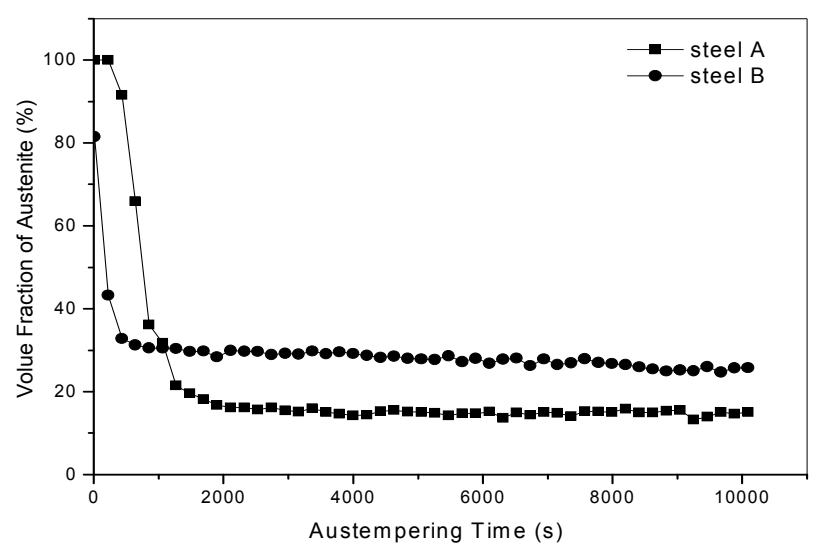

Fig.1 Volume fraction of austenite during austempering transformation at $280^{\circ} \mathrm{C}$

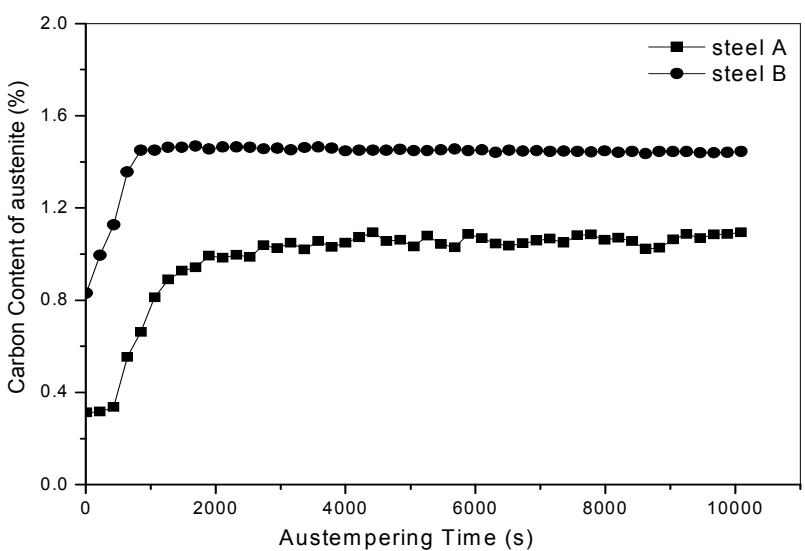

Fig.2 Carbon content of austenite during austempering transformation at $280^{\circ} \mathrm{C}$

The carbon concentration of austenite of the in-situ X-ray analyses of the bainitic transformation varying with the austempering time is shown in Figure 2. The carbon contents of austenite were calculated by using the lattice parameter of austenite $\alpha_{\gamma}$. To calculate the lattice parameters at austempering temperature the thermal expansion coefficient of austenite must be measured. The thermal expansion coefficient of austenite was measured to be $2.72 \times 10^{-5} \mathrm{~K}^{-1}$ and $2.51 \times 10^{-5} \mathrm{~K}^{-1}$ for steel A and B respectively. The carbon content of austenite increases with austempering time and then attains a constant value, which provides a further evidence that the transformation has finished, after the early stages of transformation for both steels when austempered at $280^{\circ} \mathrm{C}$.

Figure 3 shows examples of curve fitting the X-ray diffraction line profiles of the austenite during the isothermal transformation, by using the Gaussian function. Asymmetrical diffraction peaks were obtained after the first ferrite peak was detected for both steels (Figure 3(a), (c)). This asymmetry of the diffraction peaks after the formation of bainitic ferrite can not be explained with instrumental errors. This is attributed to a heterogeneous distribution of carbon in different regions of austenite, because it takes time for carbon to become homogenised after it is partitioned from supersaturated bainitic ferrite [14]. The result shows exactly that two types of austenite with different carbon contents exist during the transformation: low-carbon austenite $\left(\gamma_{\mathrm{LC}}\right)$ which corresponds to the initial austenite and the high-carbon austenite $\left(\gamma_{\mathrm{HC}}\right)$ between sub-units and laths of bainitic ferrite. For both steels after holding for the first ferrite peak was detected, the model function with two peaks fits adequately to the whole line profile. The higher diffraction angle peak corresponds to the low-carbon austenite $\left(\gamma_{\mathrm{LC}}\right)$ and the lower to the high-carbon austenite $\left(\gamma_{\mathrm{HC}}\right)$. Further to the left shift of the $\gamma_{\mathrm{HC}}$ peak of steel B (Figure 3(c)) indicates that the carbon content is higher than steel A (Figure 3(a)). For the sample of steel A austempered for 1690 seconds (Figure 3(b)) and steel B austempered for 870 seconds (Figure 3(d)), which means that the transformation of bainitic ferrite has finished, a single austenite peak $\{111\}$ exists and the line profile of this single peak could be exactly fitted by the model function which indicates that the austenite $\left(\gamma_{\mathrm{HC}}\right)$ is carbon enriched and the transformation has ceased and remains incomplete. 

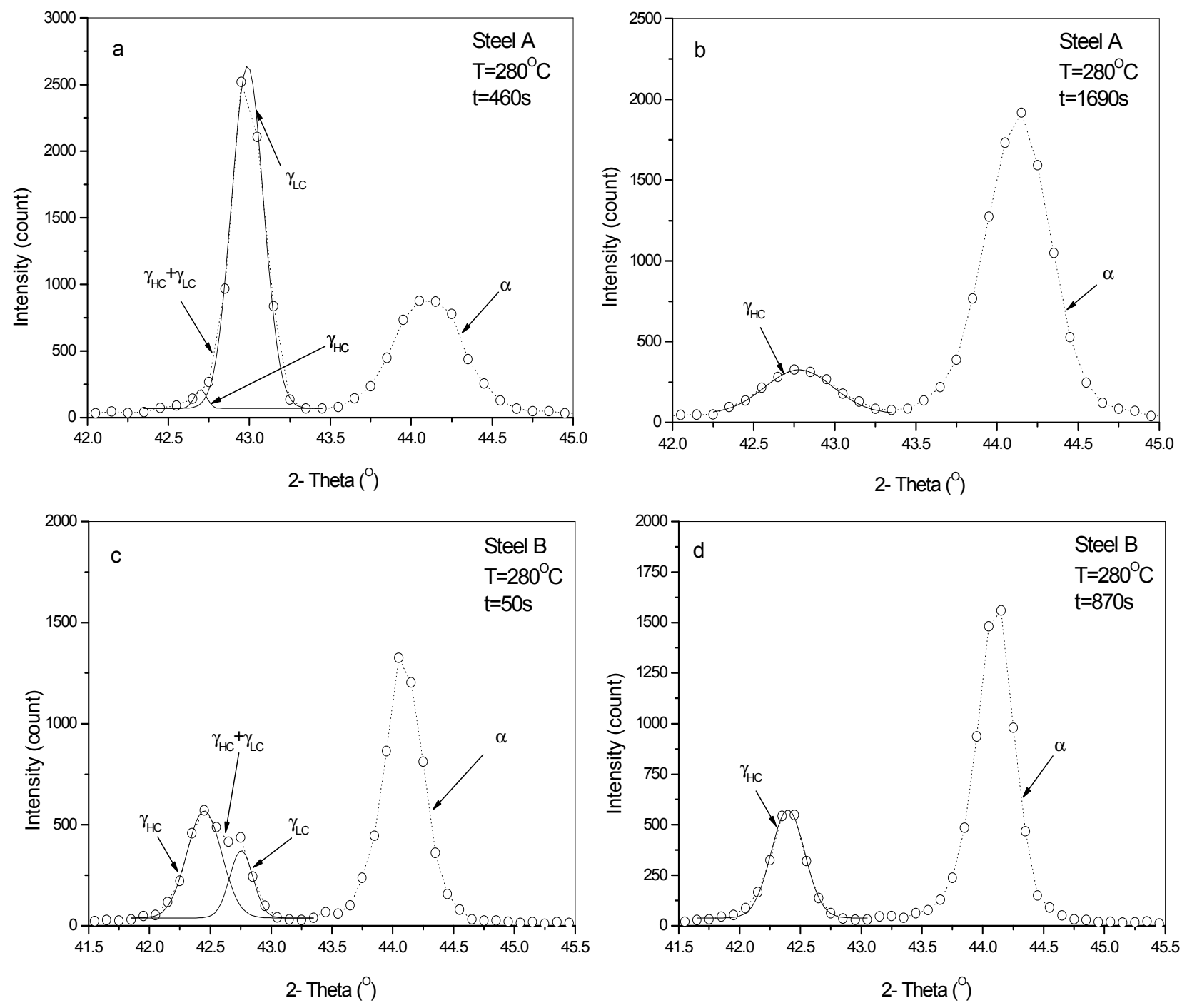

Fig. 3 X-ray diffraction line profile (open circle) of austenite $\{111\}$ during austempering transformation and the curve fitted to the line profile by Gaussian function, held for a) $460 \mathrm{~s}$ and b) $1690 \mathrm{~s}$ for steel $\mathrm{A}, \mathrm{c}$ ) $50 \mathrm{~s}$ and d) $870 \mathrm{~s}$ for steel $\mathrm{B}$, austempered at $280^{\circ} \mathrm{C}$

The microstructures of the two steels cooled to room temperature after austempering for 10560 seconds austempered at $280^{\circ} \mathrm{C}$ are given in Figure 4.
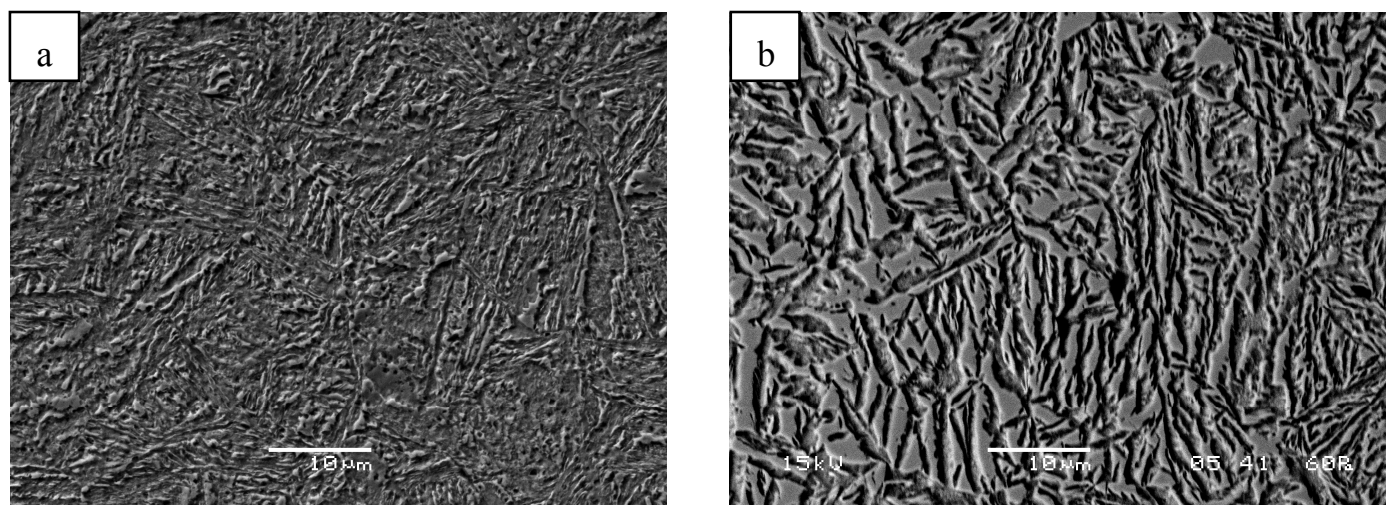

Fig. 4 Microstructure after completion of austempering transformation for 10560 seconds of a) steel A and b) steel B 
It can be seen that the microstructures consist of colonies of finer bainitic ferrite and carbon-enriched retained austenite. No carbides were precipitated in the structure because the silicon has delayed the austempering transformation of austenite. The micrograph shows that there should be two typical untransformed austenite morphologies, interlath film shaped austenite and blocky austenite between the bainitic ferrite sheaves during the isothermal transformation. Due to its high average carbon content, the amount of blocky-shaped retained austenite of steel B is larger than that of steel A.

\section{Lattice parameter of bainitic ferrite during in-situ evolution of transformation}

Figure 5 shows the variation of the lattice parameter of bainitic ferrite during isothermal transformation based on XRD pattern peaks without taking into account the influence of the thermal expansion coefficient of ferrite.

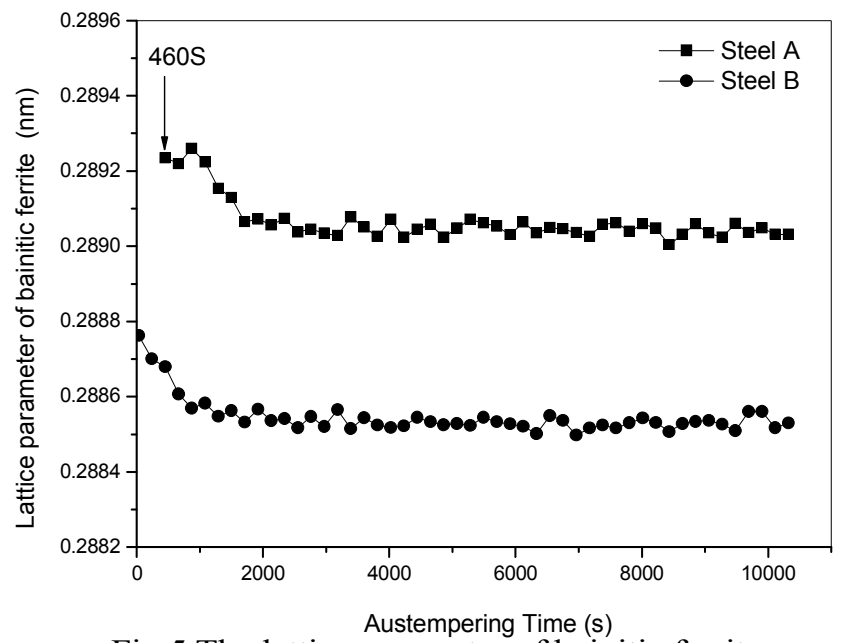

Fig.5 The lattice parameter of bainitic ferrite

as a function of time during austempering transformation

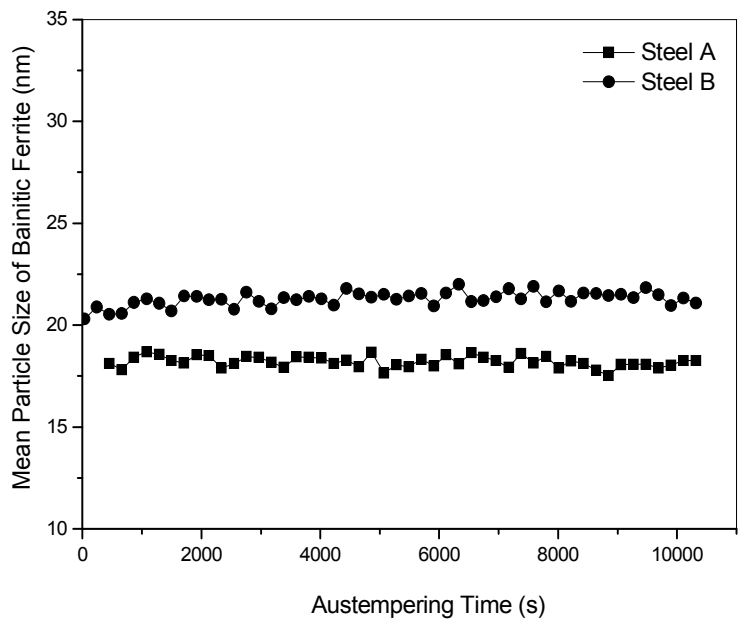

Fig. 6 The estimated mean particle size $d$ of bainitic ferrite as a function of time during austempering transformation

For steel A, there is a nucleation period of about 460 seconds before the onset of the austenite to bainitic ferrite transformation. For steel B, there is unlikely to steel A, no nucleation period before the onset of the transformation. For both steels the lattice parameter of bainitic ferrite decreases greatly in the beginning of the transformation, and then remains constant as the austempering holding time increases. It should be noted that the lattice parameter of bainitic ferrite decreases simultaneously with the decrease of the austenite shown in Figure 1. It is due to the bainitic ferrite is supersaturated with carbon as the steel is cooled down from the austenitizing temperature, and then some carbon diffuses into austenite during the isothermal transformation, giving rise to a decrease in the lattice parameter of bainitic ferrite. The transformation is almost finished when the volume fractions of austenite do not change anymore, so the lattice parameter of bainitic ferrite does not change either.

It seems that the bainitic ferrite growth at the early stage of transformation is not by the "diffusive" mechanism. It is known that the transformation temperature that distinguishes upper and lower bainite transformation is approximately $350^{\circ} \mathrm{C}$ [18]. Combining with the analysis results that the lattice parameter of bainitic ferrite decreases greatly at the early stage of transformation (Figure 5) and the volume fraction and carbon content of austenite remains constant (Figure 1 and 2), one can therefore provide further support for a mechanism in which bainite growth is diffusionless, with carbon partitioning occurring subsequent to transformation when austempered at the $280^{\circ} \mathrm{C}$.

In order to give further evidence to support the diffusionless mechanism, the primary bainitic ferrite 
lath thickening process during the subsequent isothermal holding was analyzed. Fig. 6 is a plot of the ferritic particle size against the austempering time without taking into account the influence of the thermal expansion coefficient of ferrite. The estimated ferritic particle size $d$ was obtained from the breadth of the (110) diffraction peak of ferrite using the Scherrer formula [4,19]:

$$
d=0.9 \lambda /(\beta \cos \theta)
$$

where $d$ is the particle size, $\lambda$ is the wave length of radiation, $\beta$ is the width at half maximum intensity and $\theta$ is the Bragg angle. The mean particle size $d$ is a measure of the bainitic ferrite laths width within the bainitic ferrite packet.

One can clearly observe that ferritic particle size $d$ remains a constant as the austempering holding time increases for both steels. This result suggests that the bainitic ferrite in silicon alloyed steels forms by a diffusionless mechanism with the glissile movement of coherent interface boundary [20] and carbon partitioning from bainitic ferrite to untransformed austenite.

\section{Summary}

The in-situ X-ray diffraction observations of the bainitic transformation of silicon alloyed steels were performed using the high temperature X-ray diffraction technique. The volume fraction and carbon content of austenite ceases to a constant value which indicate that the transformation is almost finished after the early stages of austempering transformation.

Asymmetry diffraction peaks are obtained for both steels at the early stage of transformation due to a heterogeneous distribution of carbon in different regions of austenite. The result shows that two types of austenite with different carbon contents exist during the transformation: low-carbon austenite $\left(\gamma_{\mathrm{LC}}\right)$ which corresponds to the initial austenite and the high-carbon austenite $\left(\gamma_{\mathrm{HC}}\right)$ between sub-units and laths of bainitic ferrite.

It seems that the bainitic ferrite growth is not by the "diffusive" mechanism. The experimental results supports that the bainite growth is by a diffusionless mechanism, with carbon partitioning occurring subsequent to transformation, when austempering is performed at $280^{\circ} \mathrm{C}$.

\section{Acknowledgements}

The authors acknowledge financial support from Swedish Institute of Sweden (No. 200/01954/2007/China Bilateral programme). The authors are also grateful to F. G. Caballero for providing the tested steel $\mathrm{A}$.

\section{References}

[1] H.K.D.H. Bhadeshia, D.V. Edmonds: Analysis of mechanical properties and microstructure of high silicon dual phase steel. Metal sci. Vol. 14(1980), p. 41

[2] R.C. Voigt, R. Bendaly, J.F. Janowak, Y.L. Park: Development of Austempered High Silicon Cast Steel. AFS Transact. Vol. 93(1985), p. 453

[3] Y.L. Park, R.B. Gundlach, J.F. Janowak: Monitoring the Bainite Reaction during Austempering of Ductile Iron and High Silicon Cast Steel by Resistively Measurement. AFS Transact. Vol. 95(1987), p. 411

[4] S.K. Putatunda: Fracture toughness of a high carbon and high silicon steel. Mater. Sci. Eng. Vol. A297(2001), p. 31 
[5] S.K. Putatunda: Influence of austempering temperature on microstructure and fracture toughness of a high-carbon, high-silicon and high-manganese cast steel. Mater. Design Vol. 24(2003), p. 435

[6] S.K. Putatunda: Austempering of a silicon manganese cast steel. Mater. Manu. Proc. Vol. 16(2001), p. 743

[7] Y.X. Li, X. Chen: Microstructure and mechanical properties of austempered high silicon cast steel. Mater. Sci. Eng. Vol. A308(2001), p. 277

[8] E. Navara, J. Zimba: Ausferritic Ferrous Alloys - a. Challenge to Industry and Research. Acta Metall. Slovaca. Vol. 10(2004), p. 244

[9] X. Chen, Y.X. Li: Fracture toughness improvement of austempered high silicon steel by titanium, vanadium and rare earth elements multi-element modification. Mater. Sci. Eng. Vol. A444(2007), p. 298

[10] X. Chen, Y.X. Li: Effects of Ti, V and rare earth on the mechanical properties of austempered high silicon cast steel. Metall. Mater. Transac. Vol. A37(2006), p. 3215

[11] Y.K. Lee, H.C. Shin, Y.C. Jang, S.H. Kim: Effect of isothermal transformation temperature on amount of retained austenite and its thermal stability in a bainitic Fe-3\%Si-0.45\%C-X steel. Scripta Mater. Vol. 47(2002), p. 805

[12] C. Liu, Z. Zhao, S.D. Bhole: Lathlike upper bainite in a silicon steel. Mater. Sci. Eng. Vol. A434(2006), p. 289

[13] S.S. Babu, E.D. Specht, S.A. David, E. Karapetrova, P. Zschack, M. Peet, H.K.D.H. Bhadeshia: In-situ observations of lattice parameter fluctuations in austenite and transformation to bainite. Metall. Mater. Transact. Vol. A36(2005), p. 3281

[14] H.J. Stone, M.J. Peet H.K.D.H. Bhadeshia, P.J. Withers, S.S. Babu, E.D. Specht: Synchrotron X-ray studies of austenite and bainitic ferrite. Proceedings Royal Society A. Vol. 464(2008), p. 1009

[15] F.G. Caballero, H.K.D.H Bhadeshia, K.J.A. Mawella, D.G. Jones and P. Brown: Design of novel high strength bainitic steels: Part 2. Mater. Sci. Technol. Vol. 17(2001), p. 517

[16] Chester F. J., John A. L., Steve W. S. Retained austenite and its measurements by X-ray diffraction (Society of Automotive Engineers, Inc., Warrendale, PA15096, 1980).

[17] D.J. Dyson, B. Holmes: Effect of alloying additions on the lattice parameter of austenite. ISIJ Int. Vol. 208(1970), p. 469.

[18] T. Toshio, A. Toshihiko, T. Shuji: Effect of bainite transformation and retained austenite on mechanical properties of austempered spheroidal graphite cast steel. Metall. Mater. Transact. Vol. A27(1996), p. 1589

[19] B.D. Cullity and S.R.Stock: Elements of X-Ray Diffraction. 3:rd edition. Prentice Hall 2001. ISBN 0201610914

[20] Z. Lawrynowicz, A. Barbacki: Feature of bainite transformation in steels. Advances Mater. Sci. Vol. 2(2002), p. 5 